\title{
Organic laws and the principle of democracy in France and Spain
}

\begin{abstract}
During the last decades, several countries have entrenched a special subcategory of law, which is adopted by stricter procedural rules than that of the ordinary legislative process. These laws are enacted by qualified majority, by the consent of the two chambers of the legislature, and they are subject to mandatory constitutional review before their promulgation, or additional safeguards are implemented in the ordinary legislative process. In this study, I compare the experiences of two crucial legal systems, France and Spain, which provide two different frameworks of qualified law. My aim is to identify the most contested issues from the legal nature of qualified laws, and to seek the proper solutions of these issues, as well as an ideal model of qualified law. My contribution focuses on the relationship between qualified laws and the principle of democracy, and aims to open up new perspectives in this regard.
\end{abstract}

Keywords: organic laws, qualified majority, constitutional review, democracy, checks and balances, France, Spain

\begin{abstract}
ABSZTRAKT
Az utóbbi évtizedekben számos államban jelent meg egy olyan törvénytípus, amelyet a rendes jogalkotási eljáráshoz képest szigorúbb eljárási szabályok szerint kell megalkotni. Ezeket a törvényeket minősitett többséggel kell elfogadni, a törvényalkotás két házának egyetértésével, és kihirdetésük előtt kötelező az alkotmányossági felülvizsgálatuk, vagy a rendes jogalkotási eljáráshoz képest más többletgarancia alkalmazása. Ebben a tanulmányban a téma szempontjából két legfontosabb jogrendszer tapasztalatait hasonlítom össze: Franciaországét és Spanyolországét. E két jogrendszer különbözőképpen kezeli a minősitett törvényeket. Célom, hogy bemutassan a minősített törvények jogi természetével kapcsolatos föbb kérdéseket, és ezekre válaszlehetőségeket mutassak be. A tanulmány fókuszában a minősitett törvények és a demokrácia viszonya áll: e viszonyra tekintettel igyekszem a téma vizsgálatához új szempontokat adni.
\end{abstract}

Kulcsszavak: organikus törvények, minösített többség, alkotmányos felülvizsgálat, demokrácia, fékek és ellensúlyok, Franciaország, Spanyolország

As a preliminary consideration, I will identify what I understand by the term qualified law, which is known as "organic law" in France and Spain respectively. Different countries have diverse concepts of qualified law, but we can outline the general content of this notion on the basis of national constitutions. Qualified law is a special category of statutes with clear constitutional background, which covers certain domains of crucial subject matters, and which is adopted with stricter procedural rules, than the ordinary legislative process. ${ }^{1}$

* Dr. Boldizsár Szentgáli-Tóth, Research Fellow, Hungarian Academy of Sciences (Budapest), Centre for Social Sciences, Institute for Legal Studies, szentgali-toth.boldizsar@tk.mta.hu.

${ }^{1}$ Camby, Jean-Pierre: Quarante ans de lois organiques. Revue du droit public, 1998/5-6, 1686-1698; Jakab, András-Szilágyi, Emese: Sarkalatos törvények a magyar jogrendszerben. Új Magyar Közigazgatás, 2014/7, 96-110; Avril, Pierre-Gicquel, Jean-Gicquel, Jean-Eric: Droit parlementaire. Dalloz, Paris, 2014, $267-307$. 
Several expressions are used for the identification of qualified laws in the national legal instruments, such as organic law; cardinal laws; laws with constitutional force, and laws adopted by two-thirds majority. These terms show the key functions of qualified laws, which are not only constitutional, but also political, historical, and have a clear sovereignty aspect also. Organic law appears in the French, ${ }^{2}$ and the Spanish ${ }^{3}$ constitution, with this terminology focusing on the constitutional role of these texts. In Spain, these laws are part of the constitutional concept (constitutional bloc), and in most of the countries concerned, they are invoked during the constitutional review of ordinary laws. ${ }^{4}$

France and Spain represent the two main models of qualified law. However, the issue of qualified law concerns not only the two abovementioned countries, but a huge number of jurisdictions around the word. The modern history of qualified laws dates back to 1958, with the Constitution of the Fifth Republic of France. ${ }^{5}$ After the decolonization of Africa, drawing inspiration from the French model, numerous African countries from the francophone legal family, ${ }^{6}$ accepted this legal solution, and currently the constitutions of twenty-one African countries contain the category of organic law such as Algeria, ${ }^{7}$ Senegal, ${ }^{8}$ and Tunisia. ${ }^{9}$ The second wave of the spread of qualified law started after the fall of the authoritarian regimes in Spain and Portugal: ${ }^{10}$ qualified law was implemented in both constitutions, and later, from that legal family, several Latin-American countries followed this example, such as Ecuador, ${ }^{11}$ and Venezuela. ${ }^{12}$ Finally, as the third stage of spread of qualified law, this framework was added to the Hungarian, Romanian, ${ }^{13}$ and Moldovan ${ }^{14}$ constitutional systems after the democratic transition. Moreover, some former member states of the Soviet Union have also codified a concept of qualified law, but these initiatives have been repealed. There are further concepts such as constitutional laws of Italy, which are close to organic law in certain respects, but their essence and logic are inherently different, as these norms aim to complete and amend the constitution itself. ${ }^{15}$

The foregoing considerations give us some sense of the main constitutional issues, raised by the concept of qualified law, and its relationship with the principle of democracy. Each country has applied this solution to promote a clear constitutional aim, therefore, in the first chapter, I will compare the historical background of the two.

\footnotetext{
${ }^{2}$ Art. 46 of the French Constitution of 4 October 1958.

${ }^{3}$ Art. 81.1 of the Spanish Constitution.

${ }^{4}$ Conseil constitutionnel, Décision $n^{\circ}$ 66-28 DC du 8 juillet 1966. Troper, Michel-Chagnollaud, Dominique: Traité international de droit constitutionnel. Paris, Dalloz, 2012, 340.

${ }^{5}$ Art. 46 of the French Constitution of 4 October 1958.

${ }^{6}$ David, René: Les grands systèmes de droit contemporains. Dalloz, Paris, 1964, 630.

${ }^{7}$ Art. 123 of the Constitution of Algeria.

${ }^{8}$ Art. 78 of the Constitution of Senegal.

${ }^{9}$ Art. 65 of the Constitution of Tunisia.

${ }^{10}$ Art. 136.3 of the Constitution of Portugal.

${ }^{11}$ Art. 133 of the Constitution of Ecuador.

${ }^{12}$ Art. 203 of the Constitution of Venezuela.

${ }^{13}$ Art. 73 of the Constitution of Romania.

${ }^{14}$ Art. $61.2,63.1,63.3,70.2,72.1,72.3,72.4,74.1,78.2,80.3,97,99.2,108.2,111.1,111.2,115.4,133.5$ of the Constitution of Moldova.

${ }^{15}$ Bin, Roberto-Pitruzzella, Giovanni: Diritto costituzionale. Giappichelli, Torino, 2008, 322.
} 
In the second chapter, I will outline the scope of ordinary and qualified law in Spain and France, and I will argue for a narrower scope of qualified law. Furthermore, qualified law may have a special position in the hierarchy of norms, somewhere between statutory and the constitutional level, so chapter three will cover this issue. ${ }^{16}$ I will concentrate especially on the level of precision of constitutional articles in this regard. Then, the practical impact of this concept on the constitutional system and political configuration shall be taken into consideration: I will deal with the separation of powers perspective of qualified laws as the fourth chapter, which leads to the main conclusions regarding the principle of democracy. From this perspective, I have two main points, which may serve the compliance between the concept of qualified law and the principle of democracy: the narrow scope of qualified law; and the mandatory a priori review. As the main outcome, certain points will be highlighted for a potential constitution-drafting process.

\section{The historical background of organic law in France and Spain}

\subsection{The historical background of organic law in France}

Firstly, since France has consistently had a number of qualified norms even at the constitutional level, ${ }^{17}$ not surprisingly, this country was the first which incorporated the concept of qualified law in its constitutional system in 1958. Organic law had been expected to be a proper instrument to promote the aims of the framers to weaken the parliament and to rebalance separation of powers. De Gaulle had at least four considerations for weakening the legislature. Firstly, the Fourth Republic suffered from a very serious degree of instability: governments were not able to survive even a year. ${ }^{18}$ It was generally considered that the excessive weakness of the government was the main reason for this discrepancy, consequently, the legislative branch had a too broad margin of movement. De Gaulle and his colleagues intended to reduce the decisive role of the Parliament, accordingly, the distribution of public power was reconsidered in favour of the executive: Parliament would not have unlimited power to determine the organisation of state, and the executive branch would have wider competences in these fields. ${ }^{19}$

Secondly, the significant laws were modified too frequently during the Fourth Republic, in light of the preferences of the actual parliamentarian majority. We have to take into consideration that the composition of the legislation changed rapidly, and there were not any safeguards on the stability of norms. Owing to the "rationalisation of the parliamentarism," ${ }^{20}$ certain subject matters would be protected from the unlimited power of the Parliament, and the basic rules of the organisation of state would be not subject to actual political considerations.

\footnotetext{
16 Troper-Chagnollaud: op. cit., 340.

17 Camby: op. cit., 1686.

${ }^{18}$ Debré, Michel: La nouvelle Constitution. Revue française de science politique, 1959/3, 7-29. (doi: 10.3406/ rfsp.1959.402982)

19 Blacher, Philippe: Le Parlement en France. LGDJ, Paris, 2012, 11-23.

${ }^{20}$ Ardant, Philippe-Mathieu, Bertrand: Droit constitutionnel et institutions politiques. LGDJ, Paris, 2014, 344-345.
} 
Thirdly, the original constitutional framework of the Fifth Republic focused on institutional issues, and the constitutional text do not contain any catalogue of fundamental rights. ${ }^{21}$ This is the main reason why the French model of qualified law is applied only in the field of the organisation of state and fundamental rights are not covered by this concept. The founders of the Fifth Republic wanted to create a safeguard only for the basic institutions of the state, but the framers were not interested in introducing this into other possible fields, such as fundamental rights.

Fourthly, as an implicit aspect, we shall mention the fear of dictatorship, which was experienced during the Second World War under the Vichy regime. Organic laws were able not only to protect democracy from instability, but also exclude the future possibility of an authoritarian regime.

The original model of organic law was slightly modified by constitutional amendments. To set an example, the organic laws related to the Senate shall be enacted with identical terms by the two chambers. This category was created to prevent the National Assembly from having the final word on the status of the Senate. This compromise was connected to a very special political situation: French-based EU citizens were permitted to participate in local elections, but they were prevented from voting in the elections of the Senate. ${ }^{22}$

\subsection{The historical background of qualified law in Spain}

Organic laws were added to the Spanish constitutional system by the Constitution of 1978, after the fall of the Franco regime, as part of the democratic transition of the country. Despite the clear French influence, the historical background of the constitution-drafting process was completely different from that of France. Spain had a lack of democratic traditions, the two previous Spanish republics had very short lives, with these regimes failing to achieve stability, and to create efficient mechanisms to prevent authoritarian aspirations. ${ }^{23}$

Moreover, a remarkable degree of uncertainty surrounded the transition: initially, it was very questionable whether the new king was committed to democratic processes, or to trying to maintain some sort of dictatorship. Regarding these circumstances, the drafters sought for such solutions which were able to promote the self-defence of the democratic system. Indeed, the primary purpose of the framers was the creation of democratic safeguards, and organic law was one of them. Due to the numerous parties, ${ }^{24}$ and ethnicities, ${ }^{25}$ Spanish political life was very fragmented, thus, broad

${ }^{21}$ Troper, Michel: Constitutional Law. In: Berman, George A.-Picard, Etienne (eds.): Introduction to French Law. Kluwer, Paris, 2008, 13.

${ }^{22}$ Constitutional amendment of 25 June 1992.

${ }^{23}$ Comella, Victor Ferreres: The Framing of the Spanish Constitution. In: Comella, Victor Ferreres: The Constitution of Spain: A Contextual Analysis. Hart, Oxford and Portland, Oregon, 2013, 4-34.

${ }^{24}$ Bonime-Blanc, Andrea: Constitution Making and Democratization. The Spanish Paradigm. In: Miller, Laurel E.-Aucoin, Louis (eds.): Framing the State in Times of Transition. Case Studies in Constitution Making. USIP Press, Washington, 2010, 417.

${ }^{25}$ Conversi, Daniele: The Smooth Transition: Spain's 1978 Constitution and the Nationalities Question. National Identities, 2002/3, 223-244. (doi: 10.1080/1460894022000026105) 
consent was essential to outline the new structure and to maintain the integrity of the country. ${ }^{26}$ Despite the clear French influence ${ }^{27}$ the requirements of a democratic transition, the huge fear of authoritarian tendencies, the protection of integrity, and the demands of autonomous regions indicate that the scope of Spanish organic law is significantly broader than its French counterpart as will be demonstrated later.

\section{The scope of organic law}

\subsection{The scope of organic law in France}

In France, most of the organic laws cover institutional fields: inter alia, the functioning of the Parliament, ${ }^{28}$ the status of the members of the judiciary, ${ }^{29}$ the status of the Constitutional Council ${ }^{30}$ the functioning of the Economic, Social and Environmental Council, ${ }^{31}$ and the powers and actions of the Defender of Rights. ${ }^{32}$ Moreover, the limitation of sovereignty of France also falls under the scope of organic law. The most conspicuous phenomena here is the almost exclusive dominance of the institutional aspect. Since fundamental rights were not included in the original framework of the Constitution of the Fifth Republic, they are almost ineligible to fall within the scope of organic law. Since 1958, the scope of organic law was slightly extended by constitutional amendments, for instance, the Defender of Rights was referred to the qualified domain in 2008.

The organic character within the practice of the Constitutional Council is related to particular provisions and subject matters rather than certain laws, which regulates organic subject matters. ${ }^{33}$ As a consequence, there are several statutes which contain organic as well as ordinary provisions. Accordingly, in cases of legal doubt, it is the task of the Constitutional Council to determine the scope of ordinary and organic law even within the same legal text. What is more, the scope of organic law is not only a technical circle of laws, but it has also strong constitutional protection, with the help of the notion of organic character. ${ }^{34}$ Each law shall provide explicitly its character; organic laws may contain ordinary provisions, but this dispositions shall be declassified. ${ }^{35}$ By contrast, organic provisions shall not be placed within ordinary laws. ${ }^{36}$ This ambiguity shows that despite the primary role of the principle of competence, some hierarchic elements are not alien from the relationship between organic and ordinary laws in France.

\footnotetext{
${ }^{26}$ Conversi: op. cit., 230.

27 Troper-Chagnollaud: op. cit., 344.

${ }^{28}$ Art. 25.1 of the French Constitution of 4 October 1958.

${ }^{29}$ Art. 64.3 of the French Constitution of 4 October 1958.

${ }^{30}$ Art. 63 of the French Constitution of 4 October 1958.

${ }^{31}$ Art. 71 of the French Constitution of 4 October 1958.

32 Art. 71-1.3 of the French Constitution of 4 October 1958.

${ }^{33}$ Camby: op. cit., 1690.

${ }^{34}$ Conseil constitutionnel, Décision n 84-177 DC du 30 août 1984.

${ }^{35}$ Conseil constitutionnel, Décision n 75-62 DC du 28 janvier 1976; Décision n 87-228 DC du 26 juin 1987; Décision n 88-242 DC du 10 mars 1988.

${ }^{36}$ Conseil constitutionnel, Décision n 86-217 DC du 18 septembre 1986.
} 


\subsection{The scope of qualified law in Spain}

The Spanish structure differs significantly from the French approach. A separate article determines the two main areas of organic law: the statutes of the autonomic communities, and the fundamental rights and freedoms. ${ }^{37}$ Apart from this, several articles of the Spanish Constitution prescribe organic law on further institutional matters: for instance, the organisation of military forces,$^{38}$ the succession of the throne,$^{39}$ referendums ${ }^{40}$ or the organisation of the judiciary, ${ }^{41}$ and the functioning and organisation of the Constitutional Tribunal. ${ }^{42}$ Accordingly, the scope of Spanish Organic Law covers two main fields: fundamental rights and the most important institutional aspects, as the Spanish Constitutional Court have identified. The institutional framework is based on the statutes of autonomous communities however, other fields are also crucial. ${ }^{43}$

Regarding the extent of organic matters, the Spanish model is also based on particular matters, prescribed by the Constitution. For instance, in this regard, fundamental rights are exclusively those which are regulated by Art. 15-29 of the Spanish Constitution. ${ }^{44}$ Since the Spanish Constitution outlines the scope of qualified law with very broad terms, the main task of the Constitutional Tribunal is to give a rational interpretation in this regard. Within the practice of the Spanish Constitutional Court, the key term is not the organic character, or essential content of a subject, but the reserved constitutional domain for organic law..$^{45}$ If an ordinary law intervenes into the organic domain, it would be struck down by the Constitutional Tribunal.

\section{Qualified law within the hierarchy of norms}

Although in light of the national context constitutional courts apply slightly different frameworks, the main experimental issues are almost the same in the two countries. Inter alia, these issues include: whether an ordinary law could amend a qualified law; whether an ordinary law could contradict a qualified law; whether an ordinary law is entitled to intervene into the qualified domain; whether an ordinary law could include qualified provisions or vice versa; whether there is a hierarchy between ordinary and qualified laws; whether qualified law constitutes a separate legal category; whether qualified law is part of the constitutional framework. ${ }^{46}$

\footnotetext{
${ }^{37}$ Art. 81.1 of the Spanish Constitution.

${ }^{38}$ Art. 8 of the Spanish Constitution.

${ }^{39}$ Art. 57.5 of the Spanish Constitution.

${ }^{40}$ Art. 93 of the Spanish Constitution.

${ }^{41}$ Art. 122.1 of the Spanish Constitution.

42 Art. 65 of the Spanish Constitution.

43 Iliopoulos-Strangas, Julia: Cours suprêmes nationales et cours européennes: concurrence ou collaboration? In memoriam Louis Favoreu. Bruylant, Bruxelles, 2007, 153; Art. 104.1 of the Spanish Constitution.

44 Tribunal Constitucional, SJCC 76/1983 of 5 August 1983, LC 2; 160/1987 of 27 October 1987, LC 2.

45 Tribunal Constitucional, JCC 236/2007 of 7 November 2007.

${ }^{46}$ Camby: op. cit., 1688.
} 
In France, despite their clear constitutional background, the Council has clarified that organic laws do not fall within either the constitutional framework, or the constitutional bloc. ${ }^{47}$ The Constitutional Council has improved its practice during the recent decades. The approach of the Council is based on three considerations.

Firstly, the Court has recognized the different legal character of organic and ordinary statutes, but has refused to create some sort of clear hierarchy between them. ${ }^{48}$ This approach was also confirmed by the French Government, ${ }^{49}$ and by the academic literature ${ }^{50}$ Either the competence of the organic as well as the ordinary legislature enjoy the same level of constitutional protection, and both of them are prohibited from any interference in the other domain. ${ }^{51}$ From 1958, the term "organic law" has been descriptive rather than normative..$^{52}$ In other words, the relation between qualified and ordinary statute is outlined by the principle of competence instead of the principle of hierarchy. The principle of competence emphasises that ordinary and qualified law are on the same level within the hierarchy of norms, they just have separate domains of subject matter. By contrast, the principle of hierarchy means that qualified law has supreme effect over ordinary law. However, despite the consistent rejection of supremacy of organic law over ordinary law, the French framework is not absolutely clear, for instance, the prohibition of explicit or even implicit amendment of organic law by an ordinary statute refers to some sort of hierarchic order..$^{53}$

Although an organic law could clarify and complete the constitutionally prescribed scope of statutes ${ }^{54}$ this authorization do not constitute an extra constitutional power to outline the scope of organic law, hence this catalogue shall be in conformity with constitutional provisions and principles. Organic laws fall outside the constitutional bloc, ${ }^{55}$ nevertheless, the contradiction with an organic law has the same impact, as a conflict with a constitutional provision. ${ }^{56}$ Furthermore, the rules of the procedure of the two assemblies shall comply also with organic laws, ${ }^{57}$ as well as other parliamentary acts. ${ }^{58}$

The second point from the Council is the distinction between ordinary and qualified provisions within the same legal text. The competence of the organic legislator is described by particular subject matters, and not by statutes. Accordingly, a legal

\footnotetext{
${ }^{47}$ Conseil constitutionnel, Décision n 84-177 DC du 30 août 1984.

48 Camby: op. cit., 1690.

49 Documents pour servir à l'histoire de l'élaboration de la Constitution: Volume III. La Documentation française, Paris, 1991, 350.

50 Luchaire, François-Conac, Gérard: La Constitution de la Ve République. Economica, Paris, 1987, $179-207$.

51 Conseil constitutionnel, Décision n 87-234 DC du 7 janvier 1988.

${ }^{52}$ Avril-Gicquel-Gicquel: op. cit., 274.

53 Conseil constitutionnel, Décision n 96-386 DC du 30 décembre 1996.

${ }^{54}$ Art. 34.8 of the French Constitution of 4 October 1958.

55 Verpeaux, Michel-Bonnard, Maryvonne: Le Conseil constitutionnel. La documentation française, Paris, 2007, 101.

56 Conseil constitutionnel, Décision n 60-8 DC du 11 août 1960.

57 Le Pourhiet, Anne-Marie: Droit constitutionnel. Economica, Paris, 2007, 379; Conseil constitutionnel, Décision n² 2006-537 DC du 22 juin 2006; Décision n 99-419 DC du 9 novembre 1999.

${ }^{58}$ Art. 40.5 of the Regulation of the National Assembly of France.
} 
text could include the provisions from both domains, but the Council would strike down such organic provisions which are adopted under the ordinary legislative procedure. ${ }^{59}$ When an organic law includes provisions from the field of ordinary law, these provisions shall be declassified, and could be amended without the application of Art. 46 of the Constitution. The Council has established the notion of organic character, and it uses this term to demarcate the scopes of qualified and ordinary law. As a consequence, the terminology of "organic text" would be more precise than the traditional wording of organic laws, hence the organic character is related to certain provisions, and not always to whole statutes.

The third tendency in the French practice is the diversification within the category of organic law: there is some sort of hierarchy even amongst institutional acts. This legal framework does not constitute a unified legal concept, and some subgroups of organic law demand special treatment. ${ }^{60}$ On the other hand, certain ordonnances (legislative acts adopted by the executive on the basis of parliamentary authorization) ${ }^{61}$ are not allowed not only in the field of ordinary law, but also within the domain of institutional acts. ${ }^{62}$

The main considerations in Spain are similar to those in France: organic laws as legal sources are bound by the Constitution ${ }^{63}$ and by the organic law from the Constitutional Court. ${ }^{64}$ As a result, Spanish organic laws are subject to constitutional review. ${ }^{65}$ Although some hierarchic elements between organic and ordinary laws exist, ${ }^{66}$ the principle of competence is highlighted vis-à-vis the principle of hierarchy, organic law is not a separate constitutional category ${ }^{67}$ However, some hierarchic aspects are also relevant, and organic laws are considered during the constitutional review of ordinary statutes. ${ }^{68}$ Though the constitutional character of qualified laws has been rejected ${ }^{69}$ organic laws shall comply with constitutional provisions. ${ }^{70}$ The Spanish approach is more pragmatic than the French one, with the organic law being assigned to a certain domain based on subject matter. As a consequence, the distinction within a particular legal instrument is not as strong as it is in France. However, the intervention in the ordinary domain shall be prevented therefore the Constitutional Tribunal strikes out ordinary and organic provisions which infringe the

59 Conseil constitutionnel, Décision n 84-177 DC du 30 août 1984; Décision n 86-217 DC du 18 septembre 1986.

60 Camby: op. cit., 1695.

${ }^{61}$ Ardant-Mathieu: op. cit., 417-419.

${ }^{62}$ Chantebout, Bernard: Droit constitutionnel et science politique. Dalloz, Paris, 1999, 379; also for instance: Ordonnance $n^{\circ}$ 58-998 du 24 octobre 1958 portant loi organique relative aux conditions d'éligibilité et aux incompatibilités parlementaires.

${ }^{63}$ Art. 9.3 of the Spanish Constitution.

${ }^{64}$ Organic law 2/1979 on the Constitutional Court of Spain, Art. 27.2, 28.2.

65 Troper-Chagnollaud: op. cit., 344.

66 Ibid.

67 Tribunal Constitucional, JCC 236/2007 of 7 November 2007.

68 Troper-Chagnollaud: op. cit., 344-345.

69 Prakke, Lucas-Kortmann, Constantijn (eds.): Constitutional Law of 15 EU Member States. Kluwer, Deventer, 2004, 743.

70 Tribunal Constitucional, JCC 53/1985 of 11 April 1985. 
constitutionally prescribed distribution of competences respectively. ${ }^{71}$ In spite of the fact that organic laws are incorporated within the constitutional bloc in Spain, they are infra-constitutional sources of law, and their legal value is clearly between the constitutional and the statutory level. ${ }^{72}$

\section{Qualified laws from a separation of powers perspective and the principle of democracy}

To bring the principle of democracy also into the picture, in the following I will briefly outline the two main separation of powers aspect of qualified law, and as a background I will also provide the relevant procedural rules from the three countries. I refer here not to the classical sense of separation of powers with three totally different branches of power, ${ }^{73}$ but as a system of checks and balances, which provides interdependence for all relevant factors of the constitutional system. ${ }^{74}$

In case of stable majoritarian support behind the government, the absolute majority would not modify radically the separation of powers between the government and the opposition. The will of the government would be able to prevail regardless of the disagreement of the opposition. The role of absolute majority, as well as an additional vote at the end of the process ${ }^{75}$ is to provide a further check on the power of the majority: qualified statutes should not be promulgated, unless they have been supported widely by deputies, at least on the government side. These requirements have multiple functions. Broader consent is sought for the enactment of an organic statute and with the help of this heightened level of minimum support, the stability of certain circles of law could be increased. Moreover, the opposition would have a better chance to prevent the government from adopting the bill, and even a slight resistance on the government side is sufficient to put the enactment off. And this is a crucial safeguard of pluralism, and the protection of minorities and consensual democracy ${ }^{76}$ Apart from this, since most of the democratic governments are coalitional, smaller groups on the government side could play a decisive role, since their consent is needed for absolute majority. To set an example, some smaller fractions benefited from this situation regularly in France during the $1980 \mathrm{~s}^{77}$

The French and Spanish model shows that absolute majority does not tend to be the lone special requirement in the field of qualified law. However, the Spanish model (followed also by Latin-American countries) do not operate with a wide circle of guar-

71 Tribunal Constitucional, JCC 236/2007 of 7 November 2007.

72 Troper-Chagnollaud: op. cit., 346.

${ }^{73}$ Montesquieu, Charles de Secondat: The Spirit of the Laws. www.ucc.ie/archive/hdsp/Montesquieu_constitution.pdf (20. 10. 2019.).

${ }^{74}$ The Federalist Papers, No. 51. https://guides.loc.gov/federalist-papers/text-51-60\#s-lg-box-wrapper-25493427 (20. 10. 2019.).

${ }^{75}$ Art. 81.1 of the Spanish Constitution.

${ }^{76}$ Conseil constitutionnel, Décision n 2007-559 DC du 6 decembre 2007.

${ }^{77}$ Avril, Pierre: Ecrits de théorie constitutionnelle et de droit politique. Éditions Université Panthéon Assas, Paris, 2010, 267. 
antees, and organic laws differ from their ordinary counterparts only by an additional round of votes, and by the prescription of absolute majority. This is the main reason that the distinction between organic and ordinary laws is not so strict in Spain as it is in France. Indeed, in France, this concept has been completed with further elements (mandatory control of constitutionality a priori, additional procedural safeguards, bicameral consent). To show an example, within the French system, the Senate is entitled to block the legislation of the first chamber in such matters, which are related directly to the Senate. ${ }^{78}$ This competence was founded as a compromise after expanding the right to vote to EU citizens in local elections. ${ }^{79}$ In light of the traditional oppositional attitude of the French Senate, this is not only a theoretic consideration. ${ }^{80}$ Another special case is the cohabitation, when the majority of the two chambers is different. ${ }^{81}$ When the qualified majority requirement is stronger (two-third consent is needed), the concept of qualified law would be based on the consent aspect and other potential elements are neglected.

Regarding the other relevant separation of powers aspect, the relations between the Constitutional Court and political branches of power, we shall highlight the role of constitutional courts as a counterbalance on concentration of powers within the hands of political actors. ${ }^{82}$ Two main questions are to be raised here: whether the constitutional review of qualified law is mandatory or optional; and whether there is an initiative of constitutional review, or it is conducted ex officio.

As regard the first issue, the review is optional, and mostly a posteriori in Hungary $^{83}$ and in Spain. ${ }^{84}$ However, the concept of qualified law is prescribed in these systems by constitutional provisions, which are enforceable by the respective constitutional bodies. As a consequence, this constitutional concept would create additional grounds of constitutional review: the Constitutional Court is entitled to examine the prevalence of the procedural norms ${ }^{85}$ and in case of any doubt, to bind the scope of qualified and ordinary law. ${ }^{86}$ This mechanism raises the compliance not only with procedural, but also with substantial requirements. ${ }^{87}$ The details of this theoretical framework has been analyzed elsewhere, but here, we should already highlight the role of the Constitutional Court in dealing with these issues. The basis of this distinction is prescribed by the Constitution, but the relevant constitutional provisions are subject to interpretation, ${ }^{88}$ even if they are formulated by certain levels of precision.

\footnotetext{
78 Conseil constitutionnel, Décision n 85-195 DC du 10 juillet 1985.

${ }^{79}$ Amendment of the French Constitution of 25 June 1992.

${ }^{80}$ Ardant-Mathieu: op. cit., 430.

81 Le Pourhiet, Anne-Marie-Mathieu, Bertrand-Mélin-Soucramanien, Ferdinand-Rousseau, Dominique (eds.): Représentation et représentativité. Dalloz, Paris, 2008, 83.

82 Seiller, Bertrand (ed.): Le contrôle parlementaire de l'administration. Dalloz, Paris, 2010, 104.

${ }^{83}$ Art. 24 of the Fundamental Law of Hungary.

84 Organic law 2/1979 on the Constitutional Court of Spain, Art. 28.

${ }^{85}$ Conseil constitutionnel, Décision n 89-263 DC du 11 janvier 1990.

${ }^{86}$ For instance: Conseil constitutionnel, Décision n 84-177 DC du 30 août 1984; Tribunal Constitucional, JCC 11/1981 of April 8 1981; Hungarian Constitutional Court, Decision 1/1999 of 24 February 1999.

87 Conseil constitutionnel, Décision n 60-8 DC du 11 août 1960.

${ }^{88}$ Bodnár, Eszter-Módos, Mátyás: A jogalkotás normatív kereteinek változásai az új jogalkotási törvény elfogadása óta. Kodifikáció, 2012/1, 33-34.
} 
In other words, the Constitutional Court is entitled to control whether a qualified subject matter is covered exclusively by qualified law. Certain constitutional frameworks, like the French also protect the domain of ordinary law. ${ }^{89}$ The Constitutional Court as a check on the political branches would be significantly stronger.

The second model, which is more special than the previous one, is applied in France, and it cannot be understood without the consideration of the special historical background of this country. The scope of the legislation is outlined by a closed list of enumeration, ${ }^{90}$ however, this strict distinction has been relativized..$^{91}$ Nevertheless, the Constitutional Council is still entitled to prevent the Parliament from overstepping this domain. ${ }^{92}$ Therefore, the Constitutional Council has to mandatorily review all passed organic laws before their promulgation; without this step, these laws would not enter into force. ${ }^{93}$ This system would prevent, at least theoretically, unconstitutional acts in some essential fields of law. Furthermore, the position of the Constitutional Council is remarkably strengthened by this solution: without its agreement, any organic law, even if the organic law from the organisation and functioning of the Council ${ }^{94}$ would not be effective.

If the scope of control of constitutionality is narrow, and the qualified majority requirement is not so strict, the mandatory a priori review could be an effective safeguard, but we should also be aware of the risks of this mechanism. On the one hand, it would strengthen the competence of the Constitutional Court, but on the other hand, this would also be a vehicle of political engagement for the body and would undermine democratic principles..$^{95}$ Lack of direct democratic legitimacy is always a strong argument against any form of judicial review over legislation..$^{96}$

Regarding the issue of initiatives, there is a clear connection between the French system, where the prime minister is obliged to refer qualified laws before the Council without discretion, ${ }^{97}$ and the other two approaches, where an initiative is only facultative for the beginning of the review proceeding. We can classify initiatives on the basis of their binding force.

Finally, considerations of this chapter again demonstrate that a wide scope of qualified law would impose a disproportionate burden on the reigning government, therefore, the traditional principles of separation of powers and democracy would not prevail. The arguments based on separation of powers support a narrow coverage of qualified law, related to some institutional aspects, where the wide political consent is really necessary (for instance: the electoral system, and the fundamental princip-

${ }^{89}$ Conseil constitutionnel, Décision n ${ }^{\circ} 75-62$ DC du 28 janvier 1976.

${ }^{90}$ Art. 34 of the French Constitution of 4 October 1958.

${ }^{91}$ Ardant-Mathieu: op. cit., 425-476.

${ }_{92}$ Avril-Gicquel-Gicquel: op. cit., 271.

${ }^{93}$ Art. 46.5 and 61.1 of the French Constitution of 4 October 1958.

94 Julien, Thomas: L'indépendance du Conseil Constitutionnel. Doctoral dissertation, Université Libre de Bruxelles, 2010, 103; Camby, Jean-Pierre: Les archives du Conseil constitutionnel: déclaration d'indépendance. Les Petits Affiches, 24 septembre 2008, n 192, 6-14.

95 Troper-Chagnollaud: op. cit., 341-342.

${ }^{96}$ CBC - Sunday Edition: Justocracy. www.prx.org/pieces/72-cbc-sunday-edition-justocracy (20. 10. 2019.).

${ }^{97}$ Ordonnance $n^{\circ}$ 58-1067 du 7 novembre 1958 portant loi organique sur le Conseil constitutionnel. 
les of the organization of the state). With a restricted scope, the practical influence of the advantages of qualified law could be also reinforced, but the disadvantages could be played down. Therefore, as far as I am concerned, only some basic institutional matters shall be referred into the qualified domain, while other possible fields, such as fundamental rights, or political matters shall be regulated by ordinary laws, and shall be protected by other mechanisms (such as constitutional review, or international cooperation).

\section{Conclusion}

This contribution has opened up some new perspectives to conceptualize qualified law in the light of principle of democracy, and it has provided some orientations for future constitution-drafting processes in this regard. Obviously, I have not aimed to build an exclusive concept, with all details. This study covers a particular comparative approach of qualified law accordingly, and the conclusions are based on this analysis. Researching further aspects, especially within the comparative field, would reveal several other valid points.

The main grounds of this research are strongly related to each other. I would demonstrate this through the scope of qualified law. Firstly, the scope of qualified law is strongly related to the historical functions as assigned to this concept. Where the promotion of democratic transition was the essential purpose, the role of qualified majority in the protection of fundamental rights is stronger (Spain, and the original Hungarian model). In the case of priority of stability, and consent requirement, institutional issues are more important.

Secondly, the scope of qualified law would also have clear impact on the separation of powers. As a general remark, we can say that the basic rules of the organisation of state are adopted by a stricter procedure, especially by wider consent, and this would give some sort of stability for the political and administrative structure. Sometimes the relation between the central government and local entities is also concerned as a separate aspect within the separation of powers. For instance, the statutes of the Spanish autonomous communities or certain matters concerning overseas territories of France are covered by organic laws. What is more, the distribution of competences in the field of fundamental rights is remarkably different in countries where the scope of qualified law includes these rights (like in Spain).

Another crucial achievement of the analysis is the requirement of precision as regards the relevant constitutional provisions. The legal nature of qualified law is evidently subject to interpretation, but some instruments could reduce the field of judicial considerations. Firstly, constitutional provisions from qualified law shall be drafted more precisely. In addition to this, we have to admit that the selection of qualified laws is not based on any clear principle.

The outcome of my research supports the idea that in the field of qualified law, a comparative analysis can provide quite valuable experience for future references from an existing theoretical setting. This paper argued for a narrower scope of qualified law, for a careful form of mandatory a priori constitutional review of qualified 
laws, and for the clarification of their constitutional and theoretical background. In light of the national context, the introduction of these policies may be slightly different, but as general standards these points may be appropriate to make compliance between the concept of qualified law and the principle of democracy.

However, in the field of qualified law, the most relevant issue is the necessity of further extensive and deep professional discourse on this matter to seek more convenient solutions. This study is a modest contribution to this process. 